Document downloaded from:

http://hdl.handle.net/10251/97912

This paper must be cited as:

Momblanch Benavent, A.; Connor, JD.; Crossman, ND.; Paredes Arquiola, J.; Andreu Álvarez, J. (2016). Using ecosystem services to represent the environment in hydroeconomic models. Journal of Hydrology. 538:293-303. doi:10.1016/j.jhydrol.2016.04.019

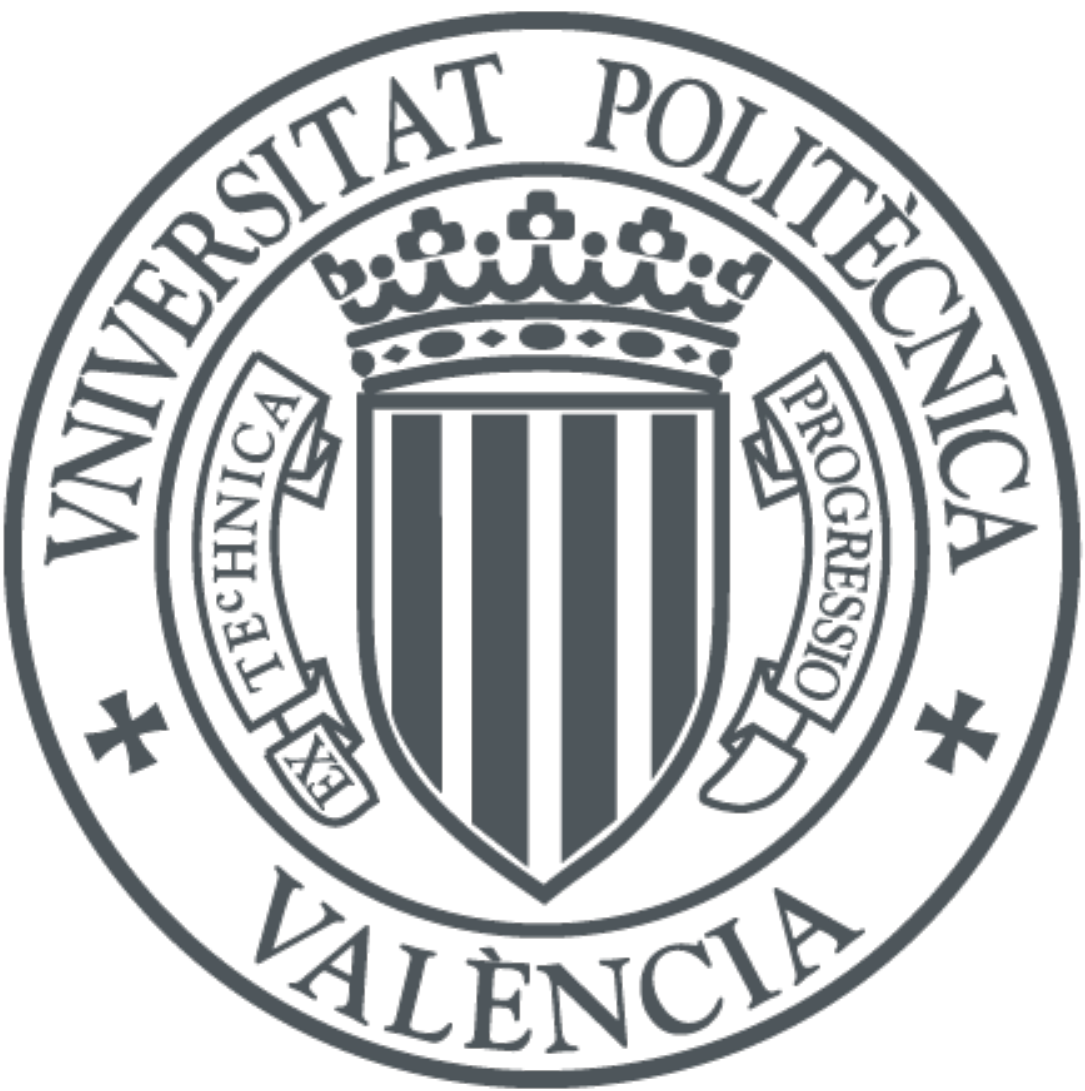

The final publication is available at

http://doi.org/10.1016/j.jhydrol.2016.04.019

Copyright Elsevier

Additional Information 
1

2

3

4

5

6

7

8

9

10

11

12

13

14

\section{Using ecosystem services to represent the environment in hydro-economic}

\section{models.}

Andrea Momblanch ${ }^{1}$, Jeffery D. Connor ${ }^{2}$, Neville D. Crossman² ${ }^{2}$ Javier Paredes-Arquiola ${ }^{1}$ and Joaquín Andreu $^{1}$

(1)

${ }^{1}$ Research Institute of Water and Environmental Engineering - Universitat Politècnica de València, Camino de Vera s/n, 46022 - Valencia, Spain

${ }^{2}$ Commonwealth Scientific and Industrial Research Organisation - Land and Water, PMB 2, Glen Osmond, SA, 5064, Australia

11

\section{$\underline{\text { Abstract }}$}

Demand for water is expected to grow in line with global human population growth, but opportunities to augment supply are limited in many places due to resource limits and expected impacts of climate change. Hydro-economic models are often used to evaluate water resources management options, commonly with a goal of understanding how to maximise water use value and reduce conflicts among competing uses. The environment is now an important factor in decision making, which has resulted in its inclusion in hydro-economic models. We reviewed 95 studies applying hydro-economic models, and documented how the environment is represented in them and the methods they use to value environmental costs and benefits. We also sought out key gaps and inconsistencies in the treatment of the environment in hydro-economic models. We found that representation of environmental values of water is patchy in most applications, and there should be systematic consideration of the scope of environmental values to include and how they should be valued. We argue that the ecosystem services framework offers a systematic approach to identify the full range of environmental costs and benefits. The main challenges to more holistic 
representation of the environment in hydro-economic models are the current limits to understanding of ecological functions which relate physical, ecological and economic values and critical environmental thresholds; and the treatment of uncertainty.

Keywords: Water resources management; Hydro-economic models; Environmental impacts; Ecosystem Services Framework

Highlights:

- Representation of the environment in hydro-economic models (HEMs) is limited

- There is no systematic inclusion of the environmental costs and benefits in HEMs

- The ecosystem services approach identifies the full range of environmental values - Accurate ecological functions and uncertainty analysis are key challenges for HEMs 
1. Introduction

Adequate flows of fresh water in rivers support food and energy production, other economic activities such as river navigation and productive fisheries, as well as clean water provision through processes such as dilution and biological degradation (Momblanch et al., 2015). All these uses compete for water resources with diverse use rights (Babel et al., 2005), and different opportunities and costs associated with adapting to less water availability (Booker, 1995).

The 1972 amendment to the US Clean Water Act established national water quality standard to preserve aquatic life, recreational uses, and their values (Copeland, 2010). Since then, there has been an increased focus on understanding the environmental and socio-economic benefits of leaving water in streams, rivers and aquifers rather than extracting it for consumptive use. For example, in the Murray-Darling Basin in Australia, Connor (2008) found that additional flows in the river could significantly reduce costs of salinity damage through dilution, and Crossman et al. (2015) documented substantial carbon sequestration, tourism, and freshwater quality values, among others, from reducing water extraction. Grossmann and Dietrich (2012) assessed carbon sequestration, boating, habitat and biodiversity values of different water management options for the Spreewald Wetland in Germany. These studies used the ecosystem services (ES) concept to report on the benefits. The core ES notion is that a wide range of natural ecosystem processes help sustain and fulfil human life (Daily et al., 1997), and that these services can be translated into economic values. Many ES are only substitutable at high economic costs, and in some cases cannot be replaced (Brauman et al., 2007; Costanza et al., 1997). For example, wetlands have the capacity to purify water by means of biochemical processes (Turner et al., 2008) with capacity being a function of wetland condition and health. The degradation of wetland ecosystems could increase treatment costs of the water extracted for consumptive use (Maltby and Barker, 2009) and/or a reduce the recreation potential (Kahil et al., 2015) leading to loss of income for the tourism industry. 
According to the $5^{\text {th }}$ assessment report of the Intergovernmental Panel on Climate Change (2014), renewable fresh water resources are likely to decrease over the $21^{\text {st }}$ century, most significantly in arid and semi-arid regions where increased frequency of drought occurrence is expected (Schwabe et al., 2013). Additionally, water demand is expected to grow with global population growth (UN 2015), resulting in more waste generation, pollution and land use expansion, which increases the pressure on land and water resources (Shama, 2004). Less water availability and lower quality, together with larger water demands, has led to increasing conflicts among water uses. Examples include conflicts between hydropower production and fisheries in the Mekong River in China (Ringler et al., 2004); irrigation and urban water uses in the Jucar and Vinalopó rivers in Spain (Andreu et al., 2009); and environmental and irrigation water uses in the Murray Darling Basin in Australia (Qureshi et al., 2007) and the Colorado River Basin in the United States (Booker and Young, 1991).

Integrated water resources management, defined as the coordinated development and management of water, land and related resources to maximise economic and social welfare without compromising the sustainability of vital ecosystems (GWP 2000), can inform decisions about water sharing in the face of competing water demands and increasing scarcity (Booker et al., 2012). Hydroeconomic models (HEMs) are one of the main tools used for integrated water resources management (Booker et al., 2012; Harou et al., 2009). HEMs combine hydrological and water infrastructure representation of water resources systems with economic demand functions for key water uses in order to allocate water subject to physical and institutional constraints (Heinz et al., 2007). HEMs typically use a node network structure with nodes representing points of diversion, inflow, outflow, storage or treatment and links between nodes representing river reach processes (Harou et al., 2009). HEMs can use optimisation or simulation approaches, but typically have the goal of allocating water among multiple uses to optimize economic value (Brouwer and Hofkes, 2008). HEMs have been used to solve water management problems for more than 50 years, and have evolved from analysing single-water use problems at water supply scale (Lefkoff and Gorelick, 1990; Wilchfort and Lund, 1997) to integrated multiple-demand and multiple-source problems at 
single river basin scale (Davidson et al., 2013b; Divakar et al., 2011) and multi-basin scale (Bekchanov et al., 2015c; Fisher et al., 2002). Groundwater representation and its connection to the surface water system have also featured in HEMs (Daneshmand et al., 2014; Pulido-Velazquez et al., 2006; Pulido-Velazquez et al., 2008a).

Several studies have reviewed HEMs. For example, Harou et al. (2009) focus on methodological aspects of HEMs, such as model formulation and design, economic valuation methods for the different water uses, and major applications. Heinz et al. (2007) discuss the role of economic approaches in water management to address the European Water Framework Directive (EC 2000) objectives, analysing diverse assessment and performance criterion, water policies and management options. Booker et al. (2012) review the advances in economic representation, policy objectives and water institutions, and level of integration and complexity of HEMs.

Consistent across reviews of HEMs is the conclusion that representation of environmental costs and benefits in HEMs is patchy and limited. For example, Harou et al. (2009) conclude that environmental water uses are rarely represented with economic value functions in HEMs, although minimum-flow constraints are included more often. They also highlight the importance of incorporating water quality processes and values which are mostly lacking in HEMs. Booker et al. (2012) argue for the expansion of HEMs to jointly tackle environmental, economic, hydrologic and institutional water resources management problems. Other reviews highlight the limited representation of environmental in-stream uses and processes in HEMs (Ringler and Cai, 2006; Ward and Pulido-Velazquez, 2009; Ward and Pulido-Velázquez, 2008), and the dearth of HEMs which account for water management changes on non-market values provided by ecosystems (Griffin and Hsu, 1993; Kragt, 2013).

There has not yet been any attempt at systematic cataloguing and critical assessment of the range of environmental impacts and values included in HEMs. Here we address this gap by: i) reviewing the range of environmental impacts included in HEMs; ii) documenting the methods used to represent 
the economic value of environmental impacts in HEMs, and; iii) making recommendations to improve the inclusion of environmental impacts and values in HEMs.

We use ES as an organising framework because it offers a systematic way to analyse the potential environmental impacts of changes to water management using the environment-economy connection. This connection is best demonstrated by the ES cascade (Potschin and Haines-Young, 2011) which shows the causal links from a change in biophysical state as a result of altered management, to the ecosystem change and then the change to ES, economic values and human well-being (Figure 1). In recent years there has been a proliferation of ES frameworks (Haines-Young and Potschin, 2013; MA 2005; TEEB 2008; UK NEA 2011). Common to all ES frameworks is the provisioning category, which are directly consumed ES products. An example is fish production in rivers that people value as food. All ES frameworks also include the regulating category for ES that arise from maintenance and moderation of environmental conditions. The capacity of wetlands to purify water by means of biochemical processes (Turner et al., 2008) is an example. Also common to ES frameworks is a category for non-consumptive values such as recreational, educational, aesthetic and spiritual. The major difference between ES frameworks is how intermediate ecosystem processes are treated. Some frameworks only include end-products or services consumed or valued directly by humans (MA 2005; Wallace, 2007), while other frameworks include environmental processes which only indirectly contribute to human welfare, such as decomposition and nutrient cycling (Boyd and Banzhaf, 2007; Costanza, 2008; Fisher and Turner, 2008). We use the Common International Classification of Ecosystem Services (CICES) (Haines-Young and Potschin, 2013) as the reference framework to classify the environmental impacts addressed by our reviewed studies. CICES supports the System of Environmental-Economic Accounting (United Nations et al., 2012) and includes only final ES (Haines-Young and Potschin, 2013) which leads to clear environment-economy links consistent with the need of HEMs to include economic demand functions.

\section{Methods}


Our review involved four stages: 1) identifying a comprehensive set of HEM studies that included representation of the environment; 2) cataloguing the selected studies according to a set key summary attributes; 3 ) applying the CICES to classify the types of environment representation in the HEMs, and; 4) cataloguing the methods used to value the environment in the HEMs.

\subsection{Literature search and selection}

We started with the set of papers reviewed by Heinz et al. (2007), Brouwer and Hofkes (2008) and Harou et al. (2009) ( $n=124)$. These were supplemented with papers from 2009 to the present using a SCOPUS search containing the key words 'hydro-economic model', 'water management', 'optimization', and 'network flow' $(n=877)$. We then refined the scope to case studies dealing with economic analysis of water management, including environmental aspects, at river basin scale $(n=$ 144). For environmental aspects we considered environmental flows, water quality in water bodies, nature related recreation activities, flood control, and broader concepts such as habitat or vegetation. We screened the titles, abstracts and journals to remove irrelevant papers ( $n=135)$, and then downloaded and read the full papers in order to select the final collection of papers $(n=95)$.

We classified all papers by year of publication and identified the water use sector to which each HEM was applied. We also documented the spatial scale of analysis, the major water management problem addressed based on the categories established in Harou et al. (2009), the assessment criteria used according to the proposal by Heinz et al. (2007), and how uncertainty was treated. We assessed whether the environment was considered as a constraint or valued in economic terms. For the papers in the latter group, we extended the review as described in sections 2.2 and 2.3 .

\subsection{Classifying representation of the environment}

We used CICES to classify the representation of the environment in the reviewed studies. CICES uses the three main ES categories of provisioning, regulating and maintenance, and cultural services. Each of these broad ES types is successively split into divisions, groups and classes, following a hierarchical structure. The elements within a level of hierarchy are conceptually similar to one another according 
to the ways they are used by people (Haines-Young and Potschin, 2013). We identified which ES in CICES are potentially provided by freshwater bodies (Table 1).

\subsection{Economic valuation methods}

167 The next step was to identify the economic valuation methods used to estimate environmental 168 values included in the HEMs. We classified valuation methods into the standard typologies common 169 throughout the literature (Costanza et al., 2011; Chee, 2004; de Groot et al., 2002; TEEB 2010; 170 Tietenberg and Lewis, 2009). The typologies we used are:

- Market value: Used when the valued ES is a good that has a market price, e.g. cultivated crop. However, for the ES whose price does not include the impact of abstraction/use on their availability for other users and the environment, e.g. drinking water, the value is derived from the marginal willingness-to-pay using econometric approaches.

- Production-based: Used when the valued ES is a factor of production for a good or service traded on the market, e.g. water for agricultural production. Value is estimated as the contribution to the net revenues obtained from the produced good or service in the market.

- Cost-based: This method approximates the value of the ES based on the costs of replacing it (replacement cost method). This approach is applicable to ES such as mediation of waste. The method can also consider the avoided mitigation damages given the presence of the ES (avoided cost method), e.g. flood protection.

- Revealed preference: Often used to value recreation and amenity values of water. The travel cost method assumes that the value of an ES can be approximated with the expenses incurred to enjoy it. This method is applicable to ES such as aquatic recreation by considering transportation expenses, on site spending and protected area entrance fees. The hedonic price method relates the value of an ES with the price variation of associated goods for different production levels or quality of the ES. A common example is the difference in market prices for real estate with more 
and less aesthetic water related amenity, assuming all other variables influencing real estate sales are equal.

190

- Stated preference: Surveys designed to elicit the values people ascribe to an ES. Respondents are usually asked how much they would be willing to pay for a specific improvement in the ES (contingent valuation method), or they are asked to select one among a number of alternatives for improvement of the ES, where price or cost required to pay for improved ES condition is a key attribute (choice experiment method). This method is applicable to non-consumptive ES such as aquatic biodiversity.

- Benefit transfer (or meta-analysis). Takes estimates of ES value from one site and applies them to another site.

In HEMs, these valuation methods are used to produce a value function for the different water uses and environmental benefits and costs, given the variation in the physical variables such as water flow or volume. In the studies we assessed, these functions are estimated using econometric or statistical methods, or by combining mathematical representations of an ecological production function with a unit production value obtained with one of the valuation approaches.

\section{Results}

\subsection{General features of the studies}

As a result of the literature search and selection, 95 papers were reviewed. Table 2 cites the final set of papers which was assigned unique ID numbers for easy citation.

The 95 papers covered the period 1984 to 2015, with less than 2 papers published per year on average prior to 2002 (Figure 2). About 6 papers were published per year on average after 2002, with the most studies in $2013(n=13)$.

We found that the water use sectors most represented by HEMs were urban, agricultural, industrial, and hydropower sectors (Table 3). Other sectors such as livestock, tourism, navigation, and industry 
were rarely included except within the twelve studies that included five or more sectors. The river basin was the most common spatial scale of the papers we reviewed. We also found that HEMs have been applied to administrative regions (15 papers: $1,18,21,22,24,26,28,32,35,36,44,45,51,55$, and 81 ), water supply systems ( 7 papers: $11,12,29,31,65,84$, and 91 ), and international regions (5 papers: $17,86,88,89$, and 90$)$.

The major water management problems tackled by the HEMs we reviewed were resource allocation, with emphases on inter-sectoral allocation $(n=48)$, water institutions $(n=13)$, and water supply infrastructure $(n=13)$. Other water issues such as drought or climate change management, transboundary water management, conjunctive surface-groundwater use, and land use management were less common. The HEMs used different types of assessment criteria to design and test water management solutions. We identified 58 papers which used a net benefit maximisation approach. Table 4 presents the number of papers addressing each major issue and the type of assessment used.

We found that there were very few studies that treated uncertainty in physical variables and parameters. Uncertainty was analysed by means of probabilistic approaches ( 2 and 11) and sensitivity analyses in deterministic models (17 and 77). Only two studies (6 and 34) assessed uncertainty of economic parameters.

We distinguished between HEMs that included economic valuation of the environment versus those that accounted for the environment using only biophysical units. We found that 61 papers considered environmental uses as constraints (e.g. 12, 33 and 93) or as decision variables in the optimisation function via ecological functions (e.g. 66 and 72). These studies mainly included minimum flows and, occasionally, water quality as environmental aspects. Some calculated the opportunity costs of environmental constraints, which provided useful economic information for decision making but did not allow comparison of environmental and other water use values. 


\subsection{Environmental impacts classification}

Among the reviewed studies, 34 defined environmental benefits and costs and used economic functions to value these within water management analysis $(2,3,5,6,7,8,9,10,11,16,27,28,29$, $30,34,37,49,53,57,60,65,67,68,71,73,74,75,77,84,88,89,90,91$, and 94$)$. The aspects of the environment considered were diverse and broadly covered vegetation and fauna, water quality and flood control. Most studies analysed only one $(2,3,5,8,9,16,30,37,49,53,57,60,68,73,74,75$, 77,84 , and 91 ) or two (i.e. $6,7,11,27,28,29,34,65,71$, and 94) environmental aspects, and only five papers covered more than three $(10,67,88,89$, and 90$)$. Table 5 uses the CICES framework to summarise the environmental impacts included in the HEMs we reviewed. Some HEMs included components of ecosystems which could not readily be allocated to the CICES framework, such as wetlands and environmental flows $(16,27,28,29,34,60,73,74,88,89,90$, and 94$)$.

We found no systematic approaches to valuation of the environment and ecosystems in HEMs although there were some recurring methods (Table 6). Production-based valuation methods were more commonly applied for provisioning ES such as commercial fishing. Water quality improvement (e.g. salt dilution and nutrients abatement) was most often valued using cost-based methods (e.g. agricultural production losses due to salinity, and treatment for drinking water). Flood control and carbon sequestration valuation were also valued with cost-based methods. Recreation activity related values were mainly estimated using the travel cost method. When valuing impacts on habitat and biodiversity, in general, or for specific natural vegetation types and native animals, stated preferences techniques were used, but in some cases results were obtained through the benefit transfer method rather than with case specific studies. Among the impacts which cannot be categorised according to CICES, benefit transfer was the main valuation technique for wetlands, and other non-specified or bespoke valuation methods were used for the environment as a general concept. The greatest diversity in valuation methods was found for environmental flows in rivers or volumes in aquifers. 
HEMs require demand functions which relate the value of the impacts to water supply. For most instream use studies, the values were dependent on river flows $(3,10,27,34,77,88,89$, and 90), whilst for uses in lakes and reservoirs values relied on the water level or the stored volume $(49,65$, 84 , and 91). Finally, there were few examples of more complex demand functions which captured the relationship between the value and the ecological response using more than one hydrological variable $(67,71$, and 94$)$.

\section{Discussion}

We selected 95 HEM studies which cover environmental aspects of water management at river basin or comparable scales. The majority of HEMs analysed inter-sectoral water allocation between two or three water use sectors, including environmental, agricultural and urban uses, with the aim of maximising net benefits. The consideration of uncertainty issues was rare. From the initial 95 studies, about two thirds considered environmental aspects in physical terms, mostly as constraints to realising other use values. The third which valued at least one environmental impact in economic terms were mostly limited to a single environmental aspect, or included very broad or vague environmental aspects. Recreation, commercial fishing and salt dilution were the most frequently valued in HEMs. We also found that established and traditional valuation methods were used to assign economic value to the environment, with little deviation from methods recommended in the ES literature (Banerjee et al., 2013; de Groot et al., 2002; TEEB 2010).

We found that the use of the ES framework to identify the aspects of the environment likely affected by alternative water management actions is a systematic and thorough way to select relevant impacts and values. The ES framework should more comprehensively capture the ecological processes, values and interactions in HEMs. To some extent, the ES approach is already influencing the inclusion of environmental and economic values in HEMs. For example, Bryan et al. (2013) selected environmental impacts based on the main water demands and the important river ecological and ES components were identified using river basin mapping. 
A reason for the poor representation of the environment, especially in economic terms, in many HEMs is the limited availability of data and models characterising relevant environmental processes and associated economic values (Dandy et al., 2013). Although good quality information is complex and costly to obtain, we think that in well studied river basins omissions may be a result of the single issue focus of many studies. Many river basins have a good knowledge base which can be used to include more environmental values. For example, water quality processes related to flow are reasonably well understood and they are not difficult to value using cost-based methods (Keeler et al., 2012; La Notte et al., 2015; Terrado et al., 2016). Similarly, it is possible to estimate values of recreational opportunities related to flow or water level (Grossmann and Dietrich, 2012; Hurd et al., 1999), and obtain values of provisioning services such as fisheries using production functions and market values (Mullick et al., 2013; Ringler and Cai, 2006), although for these ES the difficulty relies on having reliable data about underlying biophysical processes for water bodies in the basin. Environmental impacts can be valued with more than one method and, in agreement with de Groot et al. (2002), we suggest that following a rank ordering of valuation methods for each type of ES adds rigour and value comparability. Selection of the appropriate method depends on the data available and on the type of ES. Market valuation methods are generally more suited to provisioning ES or use values, cost-based methods to regulating ES, and revealed and stated preferences methods to cultural ES (TEEB 2010; Turner et al., 2008).

Uncertainty in ES values can be a consequence of the valuation approach and of the quality of the economic data. For instance, revealed and stated preference valuation methods have been criticised for their subjectivity and bias (Bateman et al., 2006; Chee, 2004; La Notte et al., 2015), while market value, production and cost based valuation techniques are more objective. Benefit transfer can increase the range of values included in HEMs when local valuation studies are absent. However, transferring values introduces additional uncertainty if there is inadequate correspondence between the original and new studies (Plummer, 2009). This uncertainty may lead to highly variable results 
Expanding the representation of the environment and its values in HEMs will likely increase model uncertainties. Since the number of ES values associated with environmental impacts can be the greatest source of uncertainty (Boithias et al., 2016), there will need to be more systematic incorporation of uncertainty analyses into HEMs, including assessment of implications of uncertainty in decision making (Cai et al., 2002). We show that very few HEMs currently treat uncertainty, a conclusion drawn by a number of other studies (Bateman et al., 2006; La Notte et al., 2015; Lund and Ferreira, 1996). We suggest that Monte Carlo based analysis, an approach used more often in integrated analysis such as integrated assessment of global climate change impacts and adaptation (Gao et al., 2016), be also used to assess uncertainty in HEMs. Monte Carlo analyses consider nonlinearities and are probabilistic, which is in line with actual measurement processes (Papadopoulos and Yeung, 2001).

Although there are arguments for expanding the number of monetised environmental values in HEMs, not all the potential environmental values impacted by water management need to be included to support good decisions. It may be the case that inclusion of additional environmental values does not influence the decision path. For example, in the case of a decision that has high net benefit based on the social, economic and environmental benefit values that are already quantified, quantifying additional benefits in monetary terms may add little to the conclusion (Kandulu et al., 2014). It may also be the case that monetised environmental values, such as those characterising productivity of wetlands or environmental flows (e.g. $€ /$ ha and $€ / \mathrm{m}^{3}$, respectively), disguise the diverse pluralistic values of the environmental assets. These aggregated values are incompatible with ES classification and valuation, though in some cases they may provide information that could be unpacked into distinct components that could be valued in an ES framework.

Something that is rarely dealt with explicitly in HEMs, despite many studies noting its importance, is the role of critical thresholds and system irreversibilities in the ecosystems response functions (Folke et al., 2002; Folke et al., 2004; Scheffer et al., 2001; Spangenberg et al., 2014). An exception is Kahil 
et al. (2015) who use a piecewise function to consider the shifts in the benefits provided by a wetland depending on inflow critical thresholds. Another aspect, not often considered in valuation functions in HEMs, is the correlation between ecological functions and other biophysical variables apart from water flows and volumes. Water quality has an important bearing on environmental aspects such as fauna and flora, and so water quality should be represented with environmental processes and linked to valuation functions. Although none of our reviewed studies consider the impact of water quality on environmental uses of water, some studies do consider impacts on traditional uses. For instance, Hurd et al. (1999) account for the impact of salinity on agricultural, urban and industrial uses. We suggest water quality variables (e.g. salinity, temperature) should be sufficiently detailed in HEMs to assess environmental impacts.

5. Conclusion

We used an ES framework to catalogue how HEMs have represented and valued the environment. Even though water management affects many environmental values, the HEMs we reviewed did not apply any systematic approaches to identify potential environmental impacts. This unsystematic approach to inclusion of the environment in HEMs risks over-looking potential trade-offs (between environment and economy) and unintended ecosystem impacts from water management decisions. The ES framework can be used to screen many environmental impacts that could be more widely applied in setting scope of analysis for water management actions.

Some important challenges remain. Firstly, the biophysical variables impacted by water management should be better understood in order to undertake a proper impact assessment and valuation. Aggregated environmental indexes which lose information about relevant detailed environmental impact values should then be avoided. Secondly, environmental functions which capture non-linearities and thresholds in ecological processes should be better defined, as should the role that water quality plays in broader aspects of environmental quality. Finally, uncertainty in 
361 both biophysical and economic variables should be more often addressed to improve the decision-

362 support capabilities of HEMs.

363 6. Acknowledgments

364 The authors acknowledge the backing of Universitat Politècnica de València through its Support

365 Programme for Research and Development. Support by the CSIRO for an internship visit by the lead

366 author is also acknowledged. We also wish to thank the European Commission for financing the

367 Seventh Framework Program project ENHANCE (FP7-ENV-2012, 308438) and the H2020 project

368 IMPREX (H2020-WATER-2014-2015, 641811), and the Spanish Ministry of Economy and

369 Competitiveness for granting the project NUTEGES (VI Plan Nacional de I+D+i 2008-2011, CGL2012-

$37034978)$. 
7. References

AHMADI, A., KARAMOUZ, M., MORIDI, A. \& HAN, D., 2012. Integrated Planning of Land Use and Water Allocation on a Watershed Scale Considering Social and Water Quality Issues. Journal of Water Resources Planning and Management. 138, 671-681.

ALCOFORADO DE MORAES, M. M., CAI, X., RINGLER, C., ALBURQUERQUE, B. E., VIEIRA DA ROCHA, S. P. \& AMORIM, C. A., 2010. Joint Water Quantity-Quality Management in a Biofuel Production Area-Integrated Economic-Hydrologic Modeling Analysis. Journal of Water Resources Planning and Management. 136, 502-511.

ANDREU, J., PÉREZ, M. Á., PAREDES-ARQUIOLA, J. \& SOLERA, A. Year. Participatory analysis of the Jucar-Vinalopo (Spain) water conflict using a Decision Support System, in: ANDERSSEN, R. S., BRADDOCK, R. D. \& NEWHAM, L. T. H., (eds.) 18th World IMACS Congress and MODSIM09 International Congress on Modelling and Simulation, July 20092009 Cairns, Australia. 32303236.

ASSIMACOPOULOS, D., BARRAQUE, D., BERLAND, J. M., FEINERMAN, E., KATSIARDI, P. \& MANOLI, E. Year. Estimation of the level of cost recovery of different scenarios of water allocation in arid areas. An easy-to-implement approach, in: Second International Workshop on Implementing economic analysis in the Water Framework Directive, February 20052005 Paris, France.

BABEL, M. S., DAS GUPTA, A. \& NAYAK, D. K., 2005. A Model for Optimal Allocation of Water to Competing Demands. Water Resources Management. 19, 693-712.

BANERJEE, O., BARK, R., CONNOR, J. \& CROSSMAN, N. D., 2013. An ecosystem services approach to estimating economic losses associated with drought. Ecological economics. 91, 19-27.

BATEMAN, I. J., BROUWER, R., DAVIES, H., DAY, B. H., DEFLANDRE, A., FALCO, S. D., GEORGIOU, S., HADLEY, D., HUTCHINS, M., JONES, A. P., KAY, D., LEEKS, G., LEWIS, M., LOVETT, A. A., NEAL, C., POSEN, P., RIGBY, D. \& KERRY TURNER, R., 2006. Analysing the Agricultural Costs and 
Non-market Benefits of Implementing the Water Framework Directive. Journal of Agricultural Economics. 57, 221-237.

BEKCHANOV, M., BHADURI, A. \& RINGLER, C., 2015a. Potential gains from water rights trading in the Aral Sea Basin. Agricultural Water Management. 152, 41-56.

BEKCHANOV, M., RINGLER, C. \& BHADURI, A., 2015b. A Water Rights Trading Approach to Increasing Inflows to the Aral Sea. Land Degradation \& Development. n/a-n/a.

BEKCHANOV, M., RINGLER, C., BHADURI, A. \& JEULAND, M., 2015c. How would the Rogun Dam affect water and energy scarcity in Central Asia? Water International. 40, 856-876.

BIELSA, J. \& DUARTE, R., 2001. An Economic Model for Water Allocation in North Eastern Spain. International Journal of Water Resources Development. 17, 397-408.

BLANCO-GUTIÉRREZ, I., VARELA-ORTEGA, C. \& PURKEY, D. R., 2013. Integrated assessment of policy interventions for promoting sustainable irrigation in semi-arid environments: A hydroeconomic modeling approach. Journal of Environmental Management. 128, 144-160.

BOITHIAS, L., TERRADO, M., COROMINAS, L., ZIV, G., KUMAR, V., MARQUÉS, M., SCHUHMACHER, M. \& ACUÑA, V., 2016. Analysis of the uncertainty in the monetary valuation of ecosystem services - A case study at the river basin scale. Science of the Total Environment. 543, Part A, 683-690.

BOOKER, J. F., 1995. Hydrologic and economic impacts of drought under alternative policy responses. Journal of the American Water Resources Association. 31, 889-906.

BOOKER, J. F., HOWITT, R. E., MICHELSEN, A. M. \& YOUNG, R. A., 2012. ECONOMICS AND THE MODELING OF WATER RESOURCES AND POLICIES. Natural Resource Modeling. 25, 168-218. BOOKER, J. F., MICHELSEN, A. M. \& WARD, F. A., 2005. Economic impact of alternative policy responses to prolonged and severe drought in the Rio Grande Basin. Water Resources Research. 41, n/a-n/a. 
BOOKER, J. F. \& YOUNG, R. A. 1991. Economic Impacts of Alternative Water Allocation Institutions in the Colorado River Basin. Completion Report. Colorado Water Resources Institute, Colorado State University.

BOOKER, J. F. \& YOUNG, R. A., 1994. Modeling Intrastate and Interstate Markets for Colorado River Water Resources. Journal of Environmental Economics and Management. 26, 66-87.

BOYD, J. \& BANZHAF, S., 2007. What are ecosystem services? The need for standardized environmental accounting units. Ecological economics. 63, 616-626.

BRAUMAN, K. A., DAILY, G. C., DUARTE, T. K. E. \& MOONEY, H. A., 2007. The Nature and Value of Ecosystem Services: An Overview Highlighting Hydrologic Services, in: ANNUAL REVIEWS (ed.) Annual review of Environment and Resources. 67-98.

BROUWER, R. \& HOFKES, M., 2008. Integrated hydro-economic modelling: Approaches, key issues and future research directions. Ecological economics. 66, 16-22.

BROWN, T. C., HARDING, B. L. \& PAYTON, E. A., 1990. Marginal Economic Value of Streamflow: A Case Study for the Colorado River Basin. Water Resources Research. 26, 2845-2859.

BRYAN, B. A., HIGGINS, A., OVERTON, I. C., HOLLAND, K., LESTER, R. E., KING, D., NOLAN, M., MACDONALD, D. H., CONNOR, J. D., BJORNSSON, T. \& KIRBY, M., 2013. Ecohydrological and socioeconomic integration for the operational management of environmental flows. Ecological Applications. 23, 999-1016.

BURKE, S. M., ADAMS, R. M. \& WALLENDER, W. W., 2004. Water banks and environmental water demands: Case of the Klamath Project. Water Resources Research. 40, n/a-n/a.

CAI, X., MCKINNEY, D. C. \& LASDON, L. S., 2002. A framework for sustainability analysis in water resources management and application to the Syr Darya Basin. Water Resources Research. 38, 21-1-21-14.

CAI, X., MCKINNEY, D. C. \& ROSEGRANT, M. W., 2003a. Sustainability analysis for irrigation water management in the Aral Sea region. Agricultural Systems. 76, 1043-1066. 
CAI, X., RINGLER, C. \& YOU, J.-Y., 2008. Substitution between water and other agricultural inputs: Implications for water conservation in a River Basin context. Ecological economics. 66, 3850.

CAI, X., ROSEGRANT, M. W. \& RINGLER, C., 2003b. Physical and economic efficiency of water use in the river basin: Implications for efficient water management. Water Resources Research. 39, n/a-n/a.

CONNOR, J., 2008. The economics of time delayed salinity impact management in the River Murray. Water Resources Research. 44, n/a-n/a.

CONNOR, J. D., FRANKLIN, B., LOCH, A., KIRBY, M. \& WHEELER, S. A., 2013. Trading water to improve environmental flow outcomes. Water Resources Research. 49, 4265-4276.

COPELAND, C. 2010. Clean Water Act: A Summary of the Law. US: Congressional Research Service.

COSTANZA, R., 2008. Ecosystem services: Multiple classification systems are needed. Biological Conservation. 141, 350-352.

COSTANZA, R., D'ARGE, R., GROOT, R. D., FARBER, S., GRASSO, M., HANNON, B., LIMBURG, K., NAEEM, S., O'NEILL, R. V., PERUELO, J., RASKIN, R. G., SUTTON, P. \& BELT, M. V. D., 1997. The value of the world's ecosystem services and natural capital. Nature. 387, 253-260.

COSTANZA, R., KUBISZEWSKI, I., ERVIN, D., BLUFFSTONE, R., BOYD, J., BROWN, D., CHANG, H., DUJON, V., GRANEK, E., POLASKY, S., SHANDAS, V. \& YEAKLEY, A., 2011. Valuing ecological systems and services. F1000 Biology Reports. 3, 14.

CROSSMAN, N. D., BARK, R. H., COLLOFF, M. J., MACDONALD, D. H. \& POLINO, C. A., 2015. Using an ecosystem services-based approach to measure the benefits of reducing diversions of freshwater: a case study in the in the Murray-Darling Basin, Australia, in: MARTIN-ORTEGA, J., FERRIER, R. C., GORDON, I. J. \& KHAN, S. (eds.), UNESCO Global Dialogue on Water Ecosystem Services. Cambridge University Press, United Kingdom, 82-89.

CHEE, Y. E., 2004. An ecological perspective on the valuation of ecosystem services. Biological Conservation. 120, 549-565. 
DANDY, G., GANJI, A., KANDULU, J. M., HATTON MACDONALD, D., MARCHI, A., MAIER, H., MANKAD, A. \& SCHMIDT, C. E. 2013. Managed Aquifer Recharge and Stormwater Use Options: Net Benefits Report. In: GOYDER INSTITUTE FOR WATER RESEARCH (ed.). Adelaide.

DANESHMAND, F., KARIMI, A., NIKOO, M., BAZARGAN-LARI, M. \& ADAMOWSKI, J., 2014. Mitigating Socio-Economic-Environmental Impacts During Drought Periods by Optimizing the Conjunctive Management of Water Resources. Water Resources Management. 28, 15171529.

DAVIDSON, B., MALANO, H., NAWARATHNA, B. \& MAHESHWARI, B., 2013a. The hydrological and economic impacts of changing water allocation in political regions within the peri-urban South Creek catchment in Western Sydney I: Model development. Journal of Hydrology. 499, 339-348.

DAVIDSON, B., MALANO, H., NAWARATHNA, B. \& MAHESHWARI, B., 2013b. The hydrological and economic impacts of changing water allocations in political regions within the peri-urban South Creek catchment in Western Sydney II: Scenarios. Journal of Hydrology. 499, 349-359.

DE GROOT, R. S., WILSON, M. A. \& BOUMANS, R. M. J., 2002. A typology for the classification, description and valuation of ecosystem functions, goods and services. Ecological economics. 41, 393-408.

DEBNATH, D., 2014. Integrating economic and hydrologic interdependence in reservoir management. Lakes and Reservoirs: Research and Management. 19, 211-224.

DEBNATH, D., BOYER, T. A., STOECKER, A. L. \& SANDERS, L. D., 2015. Nonlinear Reservoir Optimization Model with Stochastic Inflows: Case Study of Lake Tenkiller. Journal of Water Resources Planning and Management. 141, 04014046.

DIAZ, G. E., BROWN, T. C. \& MOREL-SEYTOUX, H. J. Year. The marginal economic value of streamflows: a systems approach, in: MOREL-SEYTOUX, H. J., (ed.) American Geophysical Union Twelfth Annual Hydrology Days, March 31-April 31992 Colorado State University. Fort Collins, CO. Hydrology Days Publications. Atherton, CA, 419. 
497

498

499

500

501

502

503

504

505

506

507

508

509

510

511

512

513

514

515

516

517

518

519

520

DIVAKAR, L., BABEL, M. S., PERRET, S. R. \& DAS GUPTA, A., 2011. Optimal allocation of bulk water supplies to competing use sectors based on economic criterion - An application to the Chao Phraya River Basin, Thailand. Journal of Hydrology. 401, 22-35.

DIVAKAR, L., BABEL, M. S., PERRET, S. R. \& DAS GUPTA, A., 2013. Optimal water allocation model based on satisfaction and economic benefits. International Journal of Water. 7, 363-381.

DRAPER, A., JENKINS, M. W., KIRBY, K. W., LUND, J. R. \& HOWITT, R. E., 2003. Economic-Engineering Optimization for California Water Management. Journal of Water Resources Planning and Management. 129, 155-164.

ERFANI, T., BINIONS, O. \& HAROU, J. J., 2014. Simulating water markets with transaction costs. Water Resources Research. 50, 4726-4745.

ERFANI, T., BINIONS, O. \& HAROU, J. J., 2015. Protecting environmental flows through enhanced water licensing and water markets. Hydrology Earth System Science. 19, 675-689.

EUROPEAN COMMISSION 2000. Directive 2000/60/EC of the European Parliament and of the Council, of 23 October 2000, establishing a framework for Community action in the field of water policy. Brussels: Official Journal of the European Commission.

FISHER, B. \& TURNER, R. K., 2008. Ecosystem services: Classification for valuation. Biological Conservation. 141, 1167-1169.

FISHER, F. M., ARLOSOROFF, S., ECKSTEIN, Z., HADDADIN, M., HAMATI, S. G., HUBER-LEE, A., JARRAR, A., JAYYOUSI, A., SHAMIR, U. \& WESSELING, H., 2002. Optimal water management and conflict resolution: The Middle East Water Project. Water Resources Research. 38, 25-1-2517.

FOLKE, C., CARPENTER, S., ELMQVIST, T., GUNDERSON, L., HOLLING, C. S. \& WALKER, B., 2002. Resilience and Sustainable Development: Building Adaptive Capacity in a World of Transformations. AMBIO: A Journal of the Human Environment. 31, 437-440. 
FOLKE, C., CARPENTER, S., WALKER, B., SCHEFFER, M., ELMQVIST, T., GUNDERSON, L. \& HOLLING, C. S., 2004. Regime Shifts, Resilience, and Biodiversity in Ecosystem Management. Annual Review of Ecology, Evolution, and Systematics. 35, 557-581.

GAO, L., BRYAN, B. A., NOLAN, M., CONNOR, J. D., SONG, X. \& ZHAO, G., 2016. Robust global sensitivity analysis under deep uncertainty via scenario analysis. Environmental Modelling \& Software. 76, 154-166.

GENG, G. \& WARDLAW, R., 2013. Application of Multi-Criterion Decision Making Analysis to Integrated Water Resources Management. Water Resources Management. 27, 3191-3207.

GEORGE, B., MALANO, H., DAVIDSON, B., HELLEGERS, P., BHARATI, L. \& MASSUEL, S., 2011a. An integrated hydro-economic modelling framework to evaluate water allocation strategies I: Model development. Agricultural Water Management. 98, 733-746.

GEORGE, B., MALANO, H., DAVIDSON, B., HELLEGERS, P., BHARATI, L. \& MASSUEL, S., 2011b. An integrated hydro-economic modelling framework to evaluate water allocation strategies II: Scenario assessment. Agricultural Water Management. 98, 747-758.

GIRARD, C., RINAUDO, J.-D., PULIDO-VELAZQUEZ, M. \& CABALLERO, Y., 2015. An interdisciplinary modelling framework for selecting adaptation measures at the river basin scale in a global change scenario. Environmental Modelling \& Software. 69, 42-54.

GLOBAL WATER PARTNERSHIP 2000. Integrated Water Resources Management. Background report 4.

GRAFTON, R. Q., CHU, H. L., STEWARDSON, M. \& KOMPAS, T., 2011. Optimal dynamic water allocation: Irrigation extractions and environmental tradeoffs in the Murray River, Australia. Water Resources Research. 47, n/a-n/a.

GRAFTON, R. Q. \& JIANG, Q., 2011. Economic effects of water recovery on irrigated agriculture in the Murray-Darling Basin. Australian Journal of Agricultural and Resource Economics. 55, 487499. 
GRIFFIN, R. C. \& HSU, S.-H., 1993. The Potential for Water Market Efficiency When Instream Flows Have Value. American Journal of Agricultural Economics. 75, 292-303.

GROSSMANN, M. \& DIETRICH, O., 2012. Integrated Economic-Hydrologic Assessment of Water Management Options for Regulated Wetlands Under Conditions of Climate Change: A Case Study from the Spreewald (Germany). Water Resources Management. 26, 2081-2108.

HAINES-YOUNG, R. \& POTSCHIN, M. 2013. Common International Classification of Ecosystem Services (CICES): Consultation of Version 4, August-December 2012. EEA Framework Contract No EEA/IEA/09/003.

HAROU, J. J. \& LUND, J. R., 2008. Ending groundwater overdraft in hydrologic-economic systems. Hydrogeology Journal. 16, 1039-1055.

HAROU, J. J., MEDELLÍN-AZUARA, J., ZHU, T., TANAKA, S. K., LUND, J. R., STINE, S., OLIVARES, M. A. \& JENKINS, M. W., 2010. Economic consequences of optimized water management for a prolonged, severe drought in California. Water Resources Research. 46, n/a-n/a.

HAROU, J. J., PULIDO-VELAZQUEZ, M., ROSENBERG, D. E., MEDELLÍN-AZUARA, J., LUND, J. R. \& HOWITT, R. E., 2009. Hydro-economic models: Concepts, design, applications, and future prospects. Journal of Hydrology. 375, 627-643.

HASLER, B., SMART, J. C. R., FONNESBECH-WULFF, A., ANDERSEN, H. E., THODSEN, H., BLICHER MATHIESEN, G., SMEDBERG, E., GÖKE, C., CZAJKOWSKI, M., WAS, A., ELOFSSON, K., HUMBORG, C., WOLFSBERG, A. \& WULFF, F., 2014. Hydro-economic modelling of costeffective transboundary water quality management in the Baltic Sea. Water Resources and Economics. 5, 1-23.

HEINZ, I., PULIDO-VELAZQUEZ, M., LUND, J. R. \& ANDREU, J., 2007. Hydro-economic Modeling in River Basin Management: Implications and Applications for the European Water Framework Directive. Water Resources Management. 21, 1103-1125. 
570 HOUK, E. E., FRASIER, M. \& TAYLOR, R. G., 2007. Evaluating Water Transfers from Agriculture for

571

572

573

574

575

576

577

578

579

580

581

582

583

584

585

586

587

588

589

590

591

592

593 Reducing Critical Habitat Water Shortages in the Platte Basin. Journal of Water Resources Planning and Management. 133, 320-328.

HURD, B., CALLAWAY, M., SMITH, J. B. \& KIRSHEN, P., 1999. Economic effects of climate change on US water resources. The Impact of Climate Change on the United States Economy. Cambridge University Press.

INTERGOVERNMENTAL PANEL ON CLIMATE CHANGE 2014. Climate Change 2014: Sythesis Report. Contribution of Working Groups I, II and III to the Fifth Assessment Reoprt of the Intergovernmental Panel on Climate Change. In: PACHAURI, R. K. \& MEYER, L. A. (eds.). Geneva.

JENKINS, M. W. \& LUND, J. R., 2000. Integrating Yield and Shortage Management under Multiple Uncertainties. Journal of Water Resources Planning and Management. 126, 288-297.

JENKINS, M. W., LUND, J. R., HOWITT, R. E., DRAPER, A., MSANGI, S., TANAKA, S., RITZEMA, R. S. \& MARQUES, G., 2004. Optimization of California's Water Supply System: Results and Insights. Journal of Water Resources Planning and Management. 130, 271-280.

KAHIL, M. T., DINAR, A. \& ALBIAC, J., 2015. Modeling water scarcity and droughts for policy adaptation to climate change in arid and semiarid regions. Journal of Hydrology. 522, 95109.

KANDULU, J. M., CONNOR, J. D. \& MACDONALD, D. H., 2014. Ecosystem services in urban water investment. Journal of Environmental Management. 145, 43-53.

KEELER, B. L., POLASKY, S., BRAUMAN, K. A., JOHNSON, K. A., FINLAY, J. C., O’NEILL, A., KOVACS, K. \& DALZELL, B., 2012. Linking water quality and well-being for improved assessment and valuation of ecosystem services. Proceedings of the National Academy of Sciences. 109, $18619-18624$. 
KNAPP, K. C., WEINBERG, M., HOWITT, R. \& POSNIKOFF, J. F., 2003. Water transfers, agriculture, and groundwater management: a dynamic economic analysis. Journal of Environmental Management. 67, 291-301.

KRAGT, M. E., 2013. Hydro-economic modelling in an uncertain world: Integrating costs and benefits of water quality management. Water Resources and Economics. 4, 1-21.

LA NOTTE, A., LIQUETE, C., GRIZZETTI, B., MAES, J., EGOH, B. N. \& PARACCHINI, M. L., 2015. An ecological-economic approach to the valuation of ecosystem services to support biodiversity policy. A case study for nitrogen retention by Mediterranean rivers and lakes. Ecological Indicators. 48, 292-302.

LEFKOFF, L. J. \& GORELICK, S. M., 1990. Benefits of an irrigation water rental market in a saline stream-aquifer system. Water Resources Research. 26, 1371-1381.

LETCHER, R. A., JAKEMAN, A. J. \& CROKE, B. F. W., 2004. Model development for integrated assessment of water allocation options. Water Resources Research. 40, n/a-n/a.

LI, Y. P., HUANG, G. H. \& CHEN, X., 2009. Multistage scenario-based interval-stochastic programming for planning water resources allocation. Stochastic Environmental Research and Risk Assessment. 23, 781-792.

LUND, R. J. \& FERREIRA, I., 1996. Operating Rule Optimization for Missouri River Reservoir System. Journal of Water Resources Planning and Management. 122, 287-295.

MAINUDDIN, M., KIRBY, M. \& QURESHI, M. E., 2007. Integrated hydrologic-economic modelling for analyzing water acquisition strategies in the Murray River Basin. Agricultural Water Management. 93, 123-135.

MALTBY, E. \& BARKER, T. (eds.) 2009. The wetlands handbook. John Wiley \& Sons Ltd.

MARQUES, G. F., LUND, J. R., LEU, M. R., JENKINS, M. W., HOWITT, R., HARTER, T., HATCHETT, S., RUUD, N. \& BURKE, S. M., 2006. Economically Driven Simulation of Regional Water Systems: Friant-Kern, California. Journal of Water Resources Planning and Management. 132, 468479. 
MEDELLÍN-AZUARA, J., HAROU, J. J., OLIVARES, M. A., MADANI, K., LUND, J. R., HOWITT, R. E., TANAKA, S. K., JENKINS, M. W. \& ZHU, T., 2008a. Adaptability and adaptations of California's water supply system to dry climate warming. Climatic Change. 87, 75-90.

MEDELLÍN-AZUARA, J., LUND, J. R. \& HOWITT, R. E., 2007. Water Supply Analysis for Restoring the Colorado River Delta, Mexico. Journal of Water Resources Planning and Management. 133, $462-471$.

MEDELLÍN-AZUARA, J., MENDOZA-ESPINOSA, L. G., LUND, J. R., HAROU, J. J. \& HOWITT, R. E., 2009. Virtues of simple hydro-economic optimization: Baja California, Mexico. Journal of Environmental Management. 90, 3470-3478.

MEDELLÍN-AZUARA, J., MENDOZA-ESPINOSA, L. G., LUND, J. R. \& HOWITT, R. E., 2008b. Hydroeconomic analysis of water supply for the binational transboundary region of Baja California, Mexico. Water Science and Technology: Water Supply. 8, 189-196.

MILLENNIUM ECOSYSTEM ASSESSMENT 2005. Ecosystems and human well-being. Systhesis. In: ISLAND PRESS (ed.) Ecosystems and human well-being. World Resources Institute.

MOMBLANCH, A., PAREDES-ARQUIOLA, J., MUNNÉ, A., MANZANO, A., ARNAU, J. \& ANDREU, J., 2015. Managing water quality under drought conditions in the Llobregat River Basin. Science of the Total Environment. 503-504, 300-318.

MULLICK, R. A., BABEL, M. S. \& PERRET, S. R., 2013. Marginal benefit based optimal water allocation: Case of Teesta River, Bangladesh. Water Policy. 15, 126-146.

MUNOZ-HERNÁNDEZ, A., MAYER, A. S. \& WATKINS JR, D. W., 2011. Integrated Hydrologic-EconomicInstitutional Model of Environmental Flow Strategies for Rio Yaqui Basin, Sonora, Mexico. Journal of Water Resources Planning and Management. 137, 227-237.

NEWLIN, B. D., JENKINS, M. W., LUND, J. R. \& HOWITT, R. E., 2002. Southern California Water Markets: Potential and Limitations. Journal of Water Resources Planning and Management. $128,21-32$. 
NULL, S. E. \& LUND, J. R., 2006. REASSEMBLING HETCH HETCHY: WATER SUPPLY WITHOUT O'SHAUGHNESSY DAM1. JAWRA Journal of the American Water Resources Association. 42, 395-408.

PAPADOPOULOS, C. E. \& YEUNG, H., 2001. Uncertainty estimation and Monte Carlo simulation method. Flow Measurement and Instrumentation. 12, 291-298.

PLUMMER, M. L., 2009. Assessing benefit transfer for the valuation of ecosystem services. Frontiers in Ecology and the Environment. 7, 38-45.

POTSCHIN, M. B. \& HAINES-YOUNG, R. H., 2011. Ecosystem services: Exploring a geographical perspective. Progress in Physical Geography. 35, 575-594.

PULIDO-VELAZQUEZ, M., ALVAREZ-MENDIOLA, E. \& ANDREU, J., 2013. Design of Efficient Water Pricing Policies Integrating Basinwide Resource Opportunity Costs. Journal of Water Resources Planning and Management. 139, 583-592.

PULIDO-VELAZQUEZ, M., ANDREU, J. \& SAHUQUILLO, A., 2006. Economic Optimization of Conjunctive Use of Surface Water and Groundwater at the Basin Scale. Journal of Water Resources Planning and Management. 132, 454-467.

PULIDO-VELAZQUEZ, M., ANDREU, J., SAHUQUILLO, A. \& PULIDO-VELAZQUEZ, D., 2008a. Hydroeconomic river basin modelling: The application of a holistic surface-groundwater model to assess opportunity costs of water use in Spain. Ecological Economics. 66, 51-65.

PULIDO-VELAZQUEZ, M., ANDREU, J., SAHUQUILLO, A. \& PULIDO-VELAZQUEZ, D., 2008b. Hydroeconomic river basin modelling: The application of a holistic surface-groundwater model to assess opportunity costs of water use in Spain. Ecological economics. 66, 51-65.

PULIDO-VELAZQUEZ, M., JENKINS, M. W. \& LUND, J. R., 2004. Economic values for conjunctive use and water banking in southern California. Water Resources Research. 40, n/a-n/a.

QURESHI, M. E., CONNOR, J., KIRBY, M. \& MAINUDDIN, M., 2007. Economic assessment of acquiring water for environmental flows in the Murray Basin*. Australian Journal of Agricultural and Resource Economics. 51, 283-303. 
671 REYNAUD, A. \& LEENHARDT, D. Year. MoGIRE: A Model for IntegratedWater Management, in:

672

673

674

675

676

677

678

679

680

681

682

683

684

685

686

687

688

689

690

691

692

693

694 International Congress on Environmental Modelling and Software, 2008 Barcelona, Spain.

RIEGELS, N., JENSEN, R., BENSASSON, L., BANOU, S., MØLLER, F. \& BAUER-GOTTWEIN, P., 2011. Estimating resource costs of compliance with EU WFD ecological status requirements at the river basin scale. Journal of Hydrology. 396, 197-214.

RIEGELS, N., PULIDO-VELAZQUEZ, M., DOULGERIS, C., STURM, V., JENSEN, R., MOLLER, F. \& BAUERGOTTWEIN, P., 2013. Systems Analysis Approach to the Design of Efficient Water Pricing Policies under the EU Water Framework Directive. Journal of Water Resources Planning and Management. 139, 574-582.

RINGLER, C. \& CAI, X., 2006. Valuing Fisheries and Wetlands Using Integrated Economic-Hydrologic Modeling-Mekong River Basin. Journal of Water Resources Planning and Management. $132,480-487$.

RINGLER, C., VON BRAUN, J. \& ROSEGRANT, M. W., 2004. Water Policy Analysis for the Mekong River Basin. Water International. 29, 30-42.

ROOZBAHANI, R., SCHREIDER, S. \& ABBASI, B., 2013. Economic Sharing of Basin Water Resources between Competing Stakeholders. Water Resources Management. 27, 2965-2988.

ROOZBAHANI, R., SCHREIDER, S. \& ABBASI, B., 2015. Optimal water allocation through a multiobjective compromise between environmental, social, and economic preferences. Environmental Modelling \& Software. 64, 18-30.

ROSEGRANT, M. W., RINGLER, C., MCKINNEY, D. C., CAI, X., KELLER, A. \& DONOSO, G., 2000. Integrated economic-hydrologic water modeling at the basin scale: the Maipo river basin. Agricultural Economics. 24, 33-46.

SCHEFFER, M., CARPENTER, S., FOLEY, J. A., FOLKE, C. \& WALKER, B., 2001. Catastrophic shifts in ecosystems. Nature. 413, 591-596. 
695

696

697

698

699

700

701

702

703

704

705

706

707

708

709

710

711

712

713

714

715

716

717

718

719

SCHOUPS, G., ADDAMS, C. L., MINJARES, J. L. \& GORELICK, S. M., 2006. Sustainable conjunctive water management in irrigated agriculture: Model formulation and application to the Yaqui Valley, Mexico. Water Resources Research. 42, n/a-n/a.

SCHWABE, K., ALBIAC, J., ANDREU, J., AYERS, J., CAIOLA, N., HAYMAN, P. \& IBANEZ, C., 2013. Summaries and Considerations, in: SCHWABE, K., ALBIAC, J., CONNOR, J. D., HASSAN, R. M. \& MEZA GONZÁLEZ, L. (eds.), Drought in Arid and Semi-Arid Regions. A Multi-Disciplinary and Cross-Country Perspective. Springer, 471-507.

SHAMA, P., 2004. Population Growth and Sustainable Development. Economic and Political Weekly. $39,629-633$.

SPANGENBERG, J. H., VON HAAREN, C. \& SETTELE, J., 2014. The ecosystem service cascade: Further developing the metaphor. Integrating societal processes to accommodate social processes and planning, and the case of bioenergy. Ecological economics. 104, 22-32.

TANAKA, S. K., ZHU, T., LUND, J. R., HOWITT, R. E., JENKINS, M. W., PULIDO, M. A., TAUBER, M., RITZEMA, R. S. \& FERREIRA, I. C., 2006. Climate Warming and Water Management Adaptation for California. Climatic Change. 76, 361-387.

TERRADO, M., MOMBLANCH, A., BARDINA, M., BOITHIAS, L., MUNNÉ, A., SABATER, S., SOlERA, A. \& ACUÑA, V., 2016. Integrating ecosystem services in river basin management plans. Journal of Applied Ecology. n/a-n/a.

THE ECONOMICS OF ECOSYSTEMS \& BIODIVERSITY 2008. The economics of ecosystems and biodiversity: An interim report. European Communities.

THE ECONOMICS OF ECOSYSTEMS \& BIODIVERSITY, 2010. The Economics of Ecosystems and Biodiversity Ecological and Economic Foundations, in: KUMAR, P. (ed.). Earthscan, London and Washington

TIETENBERG, T. \& LEWIS, L., 2009. Environmental \& Natural Resource Economics. Pearson Addison Wesley, Boston. 
TISDELL, J. G., 2001. The environmental impact of water markets: An Australian case-study. Journal of Environmental Management. 62, 113-120.

TURNER, R. K., GEORGIOU, S. \& FISHER, B. (eds.) 2008. Valuing Ecosystem Services: The Case of Multi-functional Wetlands. Taylor and Francis, London.

UK NATIONAL ECOSYSTEM ASSESSMENT 2011. The UK National Ecosystem Assessment: Synthesis of the Key Findings. In: UNAP-WCMC (ed.). Cambridge.

UNITED NATIONS - DEPARMENT OF ECONOMIC AND SOCIAL AFFAIRS - POPULATION DIVISION 2015. World Population Prospects: The 2015 Revision, Key Findings and Advance Tables. Working Paper No. ESA/P/WP.241.

UNITED NATIONS, EUROPEAN COMMISSION, FOOD AND AGRICULTURE ORGANIZATION OF THE UNITED NATIONS, INTERNATIONAL MONETARY FUND, ORGANISATION FOR ECONOMIC CO-OPERATION AND DEVELOPMENT \& WORLD BANK 2012. System of EnvironmentalEconomic Accounting 2012. Central Framework. In: NATIONS, U. (ed.). New York.

VARELA-ORTEGA, C., BLANCO-GUTIÉRREZ, I., SWARTZ, C. H. \& DOWNING, T. E., 2011. Balancing groundwater conservation and rural livelihoods under water and climate uncertainties: An integrated hydro-economic modeling framework. Global Environmental Change. 21, 604619.

VAUX, H. J. \& HOWITT, R. E., 1984. Managing Water Scarcity: An Evaluation of Interregional Transfers. Water Resources Research. 20, 785-792.

VOLK, M., HIRSCHFELD, J., DEHNHARDT, A., SCHMIDT, G., BOHN, C., LIERSCH, S. \& GASSMAN, P. W., 2008. Integrated ecological-economic modelling of water pollution abatement management options in the Upper Ems River Basin. Ecological economics. 66, 66-76.

WALLACE, K. J., 2007. Classification of ecosystem services: Problems and solutions. Biological Conservation. 139, 235-246. 
WAN, J., YANG, Y.-C. E., LIN, Y.-F. \& WANG, J., 2013. Groundwater Resource Planning to Preserve Streamflow: Where Environmental Amenity Meets Economic Welfare Loss. Journal of Water Resources Planning and Management. 139, 440-448.

WARD, F. A., 2009. Economics in integrated water management. Environmental Modelling \& Software. 24, 948-958.

WARD, F. A., BOOKER, J. F. \& MICHELSEN, A. M., 2006. Integrated Economic, Hydrologic, and Institutional Analysis of Policy Responses to Mitigate Drought Impacts in Rio Grande Basin. Journal of Water Resources Planning and Management. 132, 488-502.

WARD, F. A. \& LYNCH, T. P., 1996. INTEGRATED RIVER BASIN OPTIMIZATION: MODELING ECONOMIC AND HYDROLOGIC INTERDEPENDENCE. JAWRA Journal of the American Water Resources Association. 32, 1127-1138.

WARD, F. A. \& LYNCH, T. P., 1997. Is dominant use management compatible with basin-wide economic efficiency? Water Resources Research. 33, 1165-1170.

WARD, F. A. \& PULIDO-VELAZQUEZ, M., 2009. Incentive pricing and cost recovery at the basin scale. Journal of Environmental Management. 90, 293-313.

WARD, F. A. \& PULIDO-VELAZQUEZ, M., 2012. Economic Costs of Sustaining Water Supplies: Findings from the Rio Grande. Water Resources Management. 26, 2883-2909.

WARD, F. A. \& PULIDO-VELÁZQUEZ, M., 2008. Efficiency, equity, and sustainability in a water quantity-quality optimization model in the Rio Grande basin. Ecological economics. 66, 2337.

WATKINS JR, D. W. \& MCKINNEY, D. C., 1999. Screening Water Supply Options for the Edwards Aquifer Region in Central Texas. Journal of Water Resources Planning and Management. $125,14-24$.

WILCHFORT, O. \& LUND, J. R., 1997. Shortage Management Modeling for Urban Water Supply Systems. Journal of Water Resources Planning and Management. 123, 250-258. 


\section{s.}

YANG, W. \& YANG, Z., 2013. Development of a Long-term, Ecologically Oriented Dam Release Plan for the Lake Baiyangdian Sub-basin, Northern China. Water Resources Management. 27, 485-506.

YANG, W. \& YANG, Z., 2014. Analyzing Hydrological Regime Variability and Optimizing Environmental Flow Allocation to Lake Ecosystems in a Sustainable Water Management Framework: Model Development and a Case Study for China's Baiyangdian Watershed. Journal of Hydrologic Engineering. 19, 993-1005.

YANG, Y.-C. E. \& CAI, X., 2011. Reservoir Reoperation for Fish Ecosystem Restoration Using Daily Inflows-Case Study of Lake Shelbyville. Journal of Water Resources Planning and Management. 137, 470-480.

YANG, Y.-C. E., ZHAO, J. \& CAI, X., 2012. Decentralized Optimization Method for Water Allocation Management in the Yellow River Basin. Journal of Water Resources Planning and Management. 138, 313-325.

ZOLTAY, V. I., VOGEL, R. M., KIRSHEN, P. H. \& WESTPHAL, K., 2010. Integrated Watershed Management Modeling: Generic Optimization Model Applied to the Ipswich River Basin. Journal of Water Resources Planning and Management. 136, 566-575. 
Table 1. CICES framework for ecosystem accounting (v4.3) modified with the inclusion of the potential services provided 789 by water bodies.

\begin{tabular}{|c|c|c|c|c|}
\hline Section & Division & Group & Class & $\begin{array}{l}\text { Water } \\
\text { bodies* }\end{array}$ \\
\hline \multirow{16}{*}{ Provisioning } & \multirow{8}{*}{ Nutrition } & \multirow{6}{*}{ Biomass } & Cultivated crops & \\
\hline & & & Reared animals and their outputs & \\
\hline & & & Wild plants, algae and their outputs & $\checkmark$ \\
\hline & & & Wild animals and their outputs & $\checkmark$ \\
\hline & & & Plants and algae from in-situ aquaculture & $\checkmark$ \\
\hline & & & Animals from in-situ aquaculture & $\checkmark$ \\
\hline & & \multirow[t]{2}{*}{ Water } & Surface water for drinking & $\checkmark$ \\
\hline & & & Ground water for drinking & $\checkmark$ \\
\hline & \multirow[t]{5}{*}{ Materials } & \multirow[t]{3}{*}{ Biomass } & $\begin{array}{l}\text { Fibres and other materials from plants, algae } \\
\text { and animals for direct use or processing }\end{array}$ & $v$ \\
\hline & & & $\begin{array}{l}\text { Materials from plants, algae and animals for } \\
\text { agricultural use }\end{array}$ & 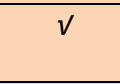 \\
\hline & & & Genetic materials from all biota & $\checkmark$ \\
\hline & & \multirow[t]{2}{*}{ Water } & Surface water for non-drinking purposes & $\checkmark$ \\
\hline & & & Ground water for non-drinking purposes & $\checkmark$ \\
\hline & \multirow[t]{3}{*}{ Energy } & \multirow{2}{*}{$\begin{array}{l}\text { Biomass-based energy } \\
\text { sources }\end{array}$} & Plant-based resources & \\
\hline & & & Animal-based resources & \\
\hline & & Mechanical energy & Animal-based energy & \\
\hline \multirow[t]{21}{*}{$\begin{array}{l}\text { Regulation \& } \\
\text { Maintenance }\end{array}$} & \multirow{5}{*}{$\begin{array}{l}\text { Mediation of } \\
\text { waste, toxics } \\
\text { and other } \\
\text { nuisances }\end{array}$} & \multirow[t]{2}{*}{ Mediation by biota } & $\begin{array}{l}\text { Bio-remediation by micro-organisms, algae, } \\
\text { plants, and animals }\end{array}$ & $v$ \\
\hline & & & $\begin{array}{l}\text { Filtration/sequestration/storage/accumulation } \\
\text { by micro-organisms, algae, plants, and animals }\end{array}$ & $\checkmark$ \\
\hline & & \multirow[t]{3}{*}{ Mediation by ecosystems } & $\begin{array}{l}\text { Filtration/sequestration/storage/accumulation } \\
\text { by ecosystems }\end{array}$ & $\checkmark$ \\
\hline & & & $\begin{array}{l}\text { Dilution by atmosphere, freshwater and } \\
\text { marine ecosystems }\end{array}$ & $\checkmark$ \\
\hline & & & Mediation of smell/noise/visual impacts & \\
\hline & \multirow{6}{*}{$\begin{array}{l}\text { Mediation of } \\
\text { flows }\end{array}$} & \multirow[t]{2}{*}{ Mass flows } & Mass stabilisation and control of erosion rates & $\checkmark$ \\
\hline & & & Buffering and attenuation of mass flows & $\checkmark$ \\
\hline & & \multirow[t]{2}{*}{ Liquid flows } & Hydrological cycle and water flow maintenance & $\checkmark$ \\
\hline & & & Flood protection & $\checkmark$ \\
\hline & & \multirow[t]{2}{*}{ Gaseous / air flows } & Storm protection & \\
\hline & & & Ventilation and transpiration & \\
\hline & \multirow{10}{*}{$\begin{array}{l}\text { Maintenance } \\
\text { of physical, } \\
\text { chemical, } \\
\text { biological } \\
\text { conditions }\end{array}$} & \multirow{2}{*}{$\begin{array}{l}\text { Lifecycle maintenance, } \\
\text { habitat and gene pool }\end{array}$} & Pollination and seed dispersal & $\checkmark$ \\
\hline & & & Maintaining nursery populations and habitats & $\checkmark$ \\
\hline & & \multirow[t]{2}{*}{ Pest and disease control } & Pest control & \\
\hline & & & Disease control & \\
\hline & & \multirow{2}{*}{$\begin{array}{l}\text { Soil formation and } \\
\text { composition }\end{array}$} & Weathering processes & \\
\hline & & & Decomposition and fixing processes & \\
\hline & & \multirow[t]{2}{*}{ Water conditions } & Chemical condition of freshwaters & \\
\hline & & & Chemical condition of salt waters & \\
\hline & & $\begin{array}{l}\text { Atmospheric composition } \\
\text { and climate regulation }\end{array}$ & $\begin{array}{l}\text { Global climate regulation by reduction of } \\
\text { greenhouse gas concentrations }\end{array}$ & $\checkmark$ \\
\hline & & & Micro and regional climate regulation & $\checkmark$ \\
\hline Cultural & $\begin{array}{l}\text { Physical and } \\
\text { intellectual }\end{array}$ & $\begin{array}{l}\text { Physical and experiential } \\
\text { interactions }\end{array}$ & $\begin{array}{l}\text { Experiential use of plants, animals and land- } \\
\text { /seascapes }\end{array}$ & $\checkmark$ \\
\hline & interactions & & Physical use of land-/seascapes & $\checkmark$ \\
\hline & & Intellectual and & Scientific & $\checkmark$ \\
\hline & & representative & Educational & $\checkmark$ \\
\hline & & interactions & Heritage, cultural & $\checkmark$ \\
\hline & & & Entertainment & $\checkmark$ \\
\hline & & & Aesthetic & $\checkmark$ \\
\hline & Spiritual, & Spiritual and/or & Symbolic & $V$ \\
\hline & symbolic and & emblematic & Sacred and/or religious & $V$ \\
\hline & other & Other cultural outputs & Existence & $\checkmark$ \\
\hline & interactions & & Bequest & $V$ \\
\hline
\end{tabular}


Table 2. Final selection of papers reviewed.

\begin{tabular}{|c|c|c|c|c|c|}
\hline ID & Citation & ID & Citation & ID & Citation \\
\hline 1 & (Vaux and Howitt, 1984) & 33 & (Pulido-Velazquez et al., 2006) & 65 & (Yang and Cai, 2011) \\
\hline 2 & (Brown et al., 1990) & 34 & (Ringler and Cai, 2006) & 66 & (Ahmadi et al., 2012) \\
\hline 3 & (Booker and Young, 1991) & 35 & (Schoups et al., 2006) & 67 & (Grossmann and Dietrich, 2012) \\
\hline 4 & (Diaz et al., 1992) & 36 & (Tanaka et al., 2006) & 68 & $\begin{array}{l}\text { (Ward and Pulido-Velazquez, } \\
\text { 2012) }\end{array}$ \\
\hline 5 & (Booker and Young, 1994) & 37 & (Ward et al., 2006) & 69 & (Yang et al., 2012) \\
\hline 6 & (Booker, 1995) & 38 & (Houk et al., 2007) & 70 & (Blanco-Gutiérrez et al., 2013) \\
\hline 7 & (Lund and Ferreira, 1996) & 39 & (Mainuddin et al., 2007) & 71 & (Bryan et al., 2013) \\
\hline 8 & (Ward and Lynch, 1996) & 40 & (Medellín-Azuara et al., 2007) & 72 & (Connor et al., 2013) \\
\hline 9 & (Ward and Lynch, 1997) & 41 & (Qureshi et al., 2007) & 73 & (Davidson et al., 2013a) \\
\hline 10 & (Hurd et al., 1999) & 42 & (Cai et al., 2008) & 74 & (Davidson et al., 2013b) \\
\hline 11 & $\begin{array}{l}\text { (Watkins Jr and McKinney, } \\
\text { 1999) }\end{array}$ & 43 & (Harou and Lund, 2008) & 75 & (Divakar et al., 2013) \\
\hline 12 & (Jenkins and Lund, 2000) & 44 & (Medellín-Azuara et al., 2008a) & 76 & (Geng and Wardlaw, 2013) \\
\hline 13 & (Rosegrant et al., 2000) & 45 & (Medellín-Azuara et al., 2008b) & 77 & (Mullick et al., 2013) \\
\hline 14 & (Bielsa and Duarte, 2001) & 46 & (Pulido-Velazquez et al., 2008b) & 78 & (Pulido-Velazquez et al., 2013) \\
\hline 15 & (Tisdell, 2001) & 47 & (Reynaud and Leenhardt, 2008) & 79 & (Riegels et al., 2013) \\
\hline 16 & (Cai et al., 2002) & 48 & (Volk et al., 2008) & 80 & (Roozbahani et al., 2013) \\
\hline 17 & (Fisher et al., 2002) & 49 & $\begin{array}{l}\text { (Ward and Pulido-Velázquez, } \\
\text { 2008) } \\
\end{array}$ & 81 & (Wan et al., 2013) \\
\hline 18 & (Newlin et al., 2002) & 50 & (Li et al., 2009) & 82 & (Yang and Yang, 2013) \\
\hline 19 & (Cai et al., 2003a) & 51 & (Medellín-Azuara et al., 2009) & 83 & (Daneshmand et al., 2014) \\
\hline 20 & (Cai et al., 2003b) & 52 & (Ward, 2009) & 84 & (Debnath, 2014) \\
\hline 21 & (Draper et al., 2003) & 53 & $\begin{array}{l}\text { (Ward and Pulido-Velazquez, } \\
\text { 2009) }\end{array}$ & 85 & (Erfani et al., 2014) \\
\hline 22 & (Knapp et al., 2003) & 54 & $\begin{array}{l}\text { (Alcoforado de Moraes et al., } \\
\text { 2010) }\end{array}$ & 86 & (Hasler et al., 2014) \\
\hline 23 & (Burke et al., 2004) & 55 & (Harou et al., 2010) & 87 & (Yang and Yang, 2014) \\
\hline 24 & (Jenkins et al., 2004) & 56 & (Zoltay et al., 2010) & 88 & (Bekchanov et al., 2015b) \\
\hline 25 & (Letcher et al., 2004) & 57 & (Divakar et al., 2011) & 89 & (Bekchanov et al., 2015c) \\
\hline 26 & (Pulido-Velazquez et al., 2004) & 58 & (George et al., 2011a) & 90 & (Bekchanov et al., 2015a) \\
\hline 27 & (Ringler et al., 2004) & 59 & (George et al., 2011b) & 91 & (Debnath et al., 2015) \\
\hline 28 & (Assimacopoulos et al., 2005) & 60 & (Grafton et al., 2011) & 92 & (Erfani et al., 2015) \\
\hline 29 & (Babel et al., 2005) & 61 & (Munoz-Hernández et al., 2011) & 93 & (Girard et al., 2015) \\
\hline 30 & (Booker et al., 2005) & 62 & (Grafton and Jiang, 2011) & 94 & (Kahil et al., 2015) \\
\hline 31 & (Marques et al., 2006) & 63 & (Riegels et al., 2011) & 95 & (Roozbahani et al., 2015) \\
\hline 32 & (Null and Lund, 2006) & 64 & (Varela-Ortega et al., 2011) & & \\
\hline
\end{tabular}

* They comprise all the river basin elements that can be affected by water management (quantity and quality): rivers
including riverbed and riverbanks; wetlands considering the different types (e.g. US Hydrogeomorphic classification or

* They comprise all the river basin elements that can be affected by water management (quantity and quality): rivers
including riverbed and riverbanks; wetlands considering the different types (e.g. US Hydrogeomorphic classification or the simplification proposed by Turner et al. (2008)); aquifers; reservoirs.

Table 3. Water use sectors considered in the reviewed HEM studies indicating the number of papers and their ID.

\begin{tabular}{|l|l|c|l|}
\hline \multicolumn{2}{|l|}{ Sectors } & $\begin{array}{c}\text { Num. } \\
\text { papers }\end{array}$ & ID papers \\
\hline $\begin{array}{l}\text { Single } \\
\text { sector }\end{array}$ & Environmental & 2 & 65,71 \\
\hline \multirow{3}{*}{$\begin{array}{l}\text { Two } \\
\text { sectors }\end{array}$} & Environmental and agricultural & 23 & $\begin{array}{l}15,22,23,25,31,35,38,39,41,48,60,61, \\
62,64,66,67,70,72,76,80,88,90,92\end{array}$ \\
\cline { 2 - 4 } & Environmental and hydropower & 2 & 8,9 \\
\cline { 2 - 4 } & Environmental and urban & 3 & $12,50,81$ \\
\hline \multirow{2}{*}{$\begin{array}{l}\text { Three } \\
\text { sectors }\end{array}$} & Environmental, agricultural and hydropower & 2 & 14,89 \\
\cline { 2 - 4 } & Environmental, agricultural and industrial & 3 & $82,85,86$ \\
\cline { 2 - 4 } & Environmental, agricultural and navigation & 1 & 77 \\
\hline
\end{tabular}




\begin{tabular}{|l|l|c|l|}
\hline \multicolumn{2}{|l|}{ Sectors } & $\begin{array}{c}\text { Num. } \\
\text { papers }\end{array}$ & ID papers \\
\hline \multirow{3}{*}{} & Environmental, urban and agricultural & 23 & $\begin{array}{l}1,18,21,24,26,28,33,37,40,43,45,46, \\
47,49,51,52,53,55,68,69,78,93,94\end{array}$ \\
\cline { 2 - 4 } & Environmental, urban and hydropower & 2 & 84,91 \\
\hline \multirow{2}{*}{$\begin{array}{l}\text { Four } \\
\text { sectors }\end{array}$} & Environmental, urban, agricultural and hydropower & 13 & $2,6,13,16,19,20,27,32,36,42,44,58,59$ \\
\cline { 2 - 4 } & Environmental, urban, agricultural and industrial & 9 & $5,17,30,73,74,79,83,87,95$ \\
\hline \multicolumn{2}{|l|}{ Five or more sectors } & 12 & $3,4,7,10,11,29,34,54,56,57,63,75$ \\
\hline
\end{tabular}

Table 4. Cross relationship between major issues and assessment criteria in the reviewed papers indicating the number

\begin{tabular}{|c|c|c|c|c|c|c|c|}
\hline $\begin{array}{l}\qquad \text { Assessment criteria } \\
\text { Major water } \\
\text { management problems }\end{array}$ & 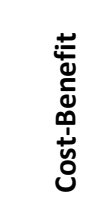 & 岕 & 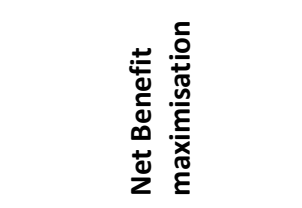 & 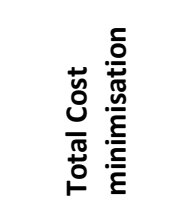 & 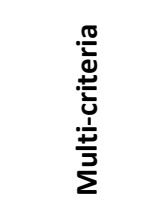 & 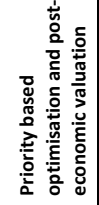 & 胥 \\
\hline $\begin{array}{l}\text { Conjunctive use of surface } \\
\text { and groundwater }\end{array}$ & 0 & 0 & $4(26,31,35,83)$ & $1(33)$ & 0 & 0 & 5 \\
\hline $\begin{array}{l}\text { Drought/climate change } \\
\text { management }\end{array}$ & 0 & 0 & $4(10,30,37,94)$ & $\begin{array}{c}3(36,44 \\
55)\end{array}$ & 0 & $1(6)$ & 8 \\
\hline Inter-sectoral water allocation & $\begin{array}{l}4(52, \\
58,59, \\
67)\end{array}$ & $\begin{array}{l}3(38, \\
64 \\
93)\end{array}$ & $\begin{array}{c}28(3,4,8,9,13,14, \\
15,20,25,39,41,42 \\
47,50,54,56,57,60 \\
61,62,69,70,77,79 \\
84,89,90,91)\end{array}$ & $1(46)$ & $\begin{array}{l}11(29,65 \\
66,71,75 \\
76,80,81 \\
82,87,95)\end{array}$ & $\begin{array}{c}1 \\
(28)\end{array}$ & 48 \\
\hline Land use management & 0 & $1(48)$ & 0 & 0 & 0 & 0 & 1 \\
\hline $\begin{array}{l}\text { Trans-boundary management } \\
\text { and conflict resolution }\end{array}$ & 0 & $1(86)$ & $5(16,17,19,27,34)$ & $1(40)$ & 0 & 0 & 7 \\
\hline $\begin{array}{l}\text { Water institutions (prices, } \\
\text { markets, rights) }\end{array}$ & 0 & 0 & $\begin{array}{c}12(1,5,18,22,23,49, \\
53,63,78,85,88,92)\end{array}$ & 0 & 0 & $\begin{array}{c}1 \\
(72)\end{array}$ & 13 \\
\hline $\begin{array}{l}\text { Water supply, engineering } \\
\text { infrastructures and capacity } \\
\text { expansion }\end{array}$ & $1(45)$ & 0 & $5(24,43,68,73,74)$ & $\begin{array}{c}6(7,11,12 \\
21,32,51)\end{array}$ & 0 & $1(2)$ & 13 \\
\hline Total & 5 & 5 & 58 & 12 & 11 & 4 & 95 \\
\hline
\end{tabular}

\begin{tabular}{|c|c|c|}
\hline Section & Class & Number of papers \\
\hline \multirow{5}{*}{ Provisioning } & Wild animals and their outputs & Commercial fishing $(11,27,34,77,88,89$, and 90$)$ \\
\hline & Surface water for drinking & \multirow{2}{*}{$\begin{array}{l}\text { Urban demands }(2,3,5,6,7,10,11,16,27,28,29,30 \text {, } \\
34,37,49,53,57,68,73,74,75,84,91 \text {, and } 94)\end{array}$} \\
\hline & Ground water for drinking & \\
\hline & Surface water for non-drinking purposes & \multirow{2}{*}{$\begin{array}{l}\text { Agricultural and/or Hydropower and/or Industrial } \\
\text { and/or Navigation and/or Livestock and/or Commercial } \\
(2,3,5,6,7,8,9,10,11,16,27,28,29,30,34,37,49 \text {, } \\
53,57,60,67,68,74,75,77,84,88,89,90,91 \text {, and 94) }\end{array}$} \\
\hline & Ground water for non-drinking purposes & \\
\hline \multirow{5}{*}{$\begin{array}{l}\text { Regulation \& } \\
\text { Maintenance }\end{array}$} & $\begin{array}{l}\text { Filtration/sequestration/storage/accumulation } \\
\text { by micro-organisms, algae, plants, and animals }\end{array}$ & \multirow{2}{*}{ Water quality (28) + Wastewater treatment (10) } \\
\hline & $\begin{array}{l}\text { Filtration/sequestration/storage/accumulation } \\
\text { by ecosystems }\end{array}$ & \\
\hline & $\begin{array}{l}\text { Dilution by atmosphere, freshwater and marine } \\
\text { ecosystems }\end{array}$ & Salt dilution $(2,3,5,6,10,57$, and 75$)+$ Waste heat $(10)$ \\
\hline & Flood protection & Flood control $(7,10$, and 65$)$ \\
\hline & $\begin{array}{l}\text { Global climate regulation by reduction of } \\
\text { greenhouse gas concentrations }\end{array}$ & Carbon sequestration (67) \\
\hline Cultural & $\begin{array}{l}\text { Experiential use of plants, animals and land- } \\
\text { /seascapes }\end{array}$ & Tourism $(88,89,90$, and 94$)$ \\
\hline
\end{tabular}




\begin{tabular}{|l|l|l|}
\hline Section & Class & Number of papers \\
\hline \multirow{3}{*}{ Physical use of land-/seascapes } & $\begin{array}{l}\text { Recreation }(6,10,11,29,30,65,84, \text { and 91) + } \\
\text { Recreational fishing }(8,9,37,49,53, \text { and 68) + Boating } \\
(67)\end{array}$ \\
\cline { 2 - 3 } & Symbolic & $\begin{array}{l}\text { Habitat (67) + Biodiversity (67) + Natural vegetation (71) } \\
+ \text { Native animals (71) }\end{array}$ \\
\hline
\end{tabular}

Table 6. Valuation methods used in HEM studies for the considered environmental and non-environmental impacts.

\begin{tabular}{|c|c|c|c|c|c|c|c|c|}
\hline & & $\begin{array}{c}\text { Consumer } \\
\text { Surplus }\end{array}$ & $\begin{array}{c}\text { Production- } \\
\text { based }\end{array}$ & Cost-based & $\begin{array}{c}\text { Revealed } \\
\text { preferences }\end{array}$ & \begin{tabular}{c|} 
Stated \\
preferences
\end{tabular} & $\begin{array}{c}\text { Benefit } \\
\text { transfer }\end{array}$ & Other \\
\hline \multirow{7}{*}{ 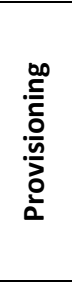 } & Commercial fishing & & +++ & & & & & \\
\hline & Urban demands & +++ & & & & & & \\
\hline & Agricultural demands & ++ & +++ & & & & & \\
\hline & Hydropower demands & & +++ & & & & & \\
\hline & Industrial demands & +++ & ++ & + & & & & \\
\hline & Navigation demands & & +++ & & & & & ++ \\
\hline & Livestock demands & & +++ & & & & & \\
\hline \multirow{6}{*}{ 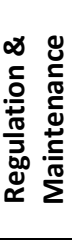 } & Water quality & & & +++ & & & & \\
\hline & Wastewater treat. & & & +++ & & & & \\
\hline & Salt dilution & & & +++ & & & & \\
\hline & Waste heat & & & +++ & & & & \\
\hline & Flood control & & & +++ & & & & ++ \\
\hline & Carbon sequestration & & & +++ & & & & \\
\hline \multirow{8}{*}{$\begin{array}{l}\overline{0} \\
\frac{7}{3} \\
\frac{3}{3}\end{array}$} & Tourism & & ++ & & +++ & & & \\
\hline & Recreation & & & & +++ & & + & ++ \\
\hline & Recreational fishing & & & & +++ & & & \\
\hline & Boating & & & & +++ & & & \\
\hline & Habitat & & & & & & +++ & \\
\hline & Biodiversity & & & & & & +++ & \\
\hline & Natural vegetation & & & & & +++ & & \\
\hline & Native animals & & & & & +++ & & \\
\hline \multirow{3}{*}{ 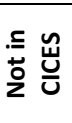 } & \begin{tabular}{|l|} 
Wetlands \\
\end{tabular} & & ++ & & & & +++ & \\
\hline & Environmental flows & & & +++ & & +++ & +++ & +++ \\
\hline & \begin{tabular}{|l|} 
Environment \\
\end{tabular} & & & & & & & +++ \\
\hline
\end{tabular}

* The most used method on which the calculation was based is indicated with +++ , the second most with ++ , and the 